\title{
THE STRUCTURE OF THE SPUR NECTARY IN Dendrobium finisterrae SCHLTR. (DENDROBIINAE, ORCHIDACEAE)
}

\author{
Magdalena Kamińska ${ }^{1}$, Małgorzata Stpiczyńska ${ }^{1,2}$ \\ ${ }^{1}$ Department of Botany, University of Life Sciences, Akademicka 15, 20-950 Lublin, \\ ${ }^{2}$ University of Warsaw, Botanic Garden, Al. Ujazdowskie 4, 00-478 Warsaw, Poland.
}

Received: 12.11.2010

\section{Abstract}

To date, the structure of the nectary spur of Dendrobium finisterrae has not been studied in detail, and the present paper compares the structural organization of the floral nectary in this species with the spurs of other taxa. The nectary spur of $D$. finisterrae was examined by means of light microscopy (LM), scanning electron microscopy (SEM), and transmission electron microscopy (TEM). It is composed of a single layer of secretory epidermis and several layers of small and compactly arranged subepidermal secretory cells. The secretory cells have thick cellulosic cell walls with primary pits. The secretory tissue is supplied by vascular bundles that run beneath in ground parenchyma and are additionally surrounded by strands of sclerenchymatous fibers. The flowers of the investigated species displayed morphological features characteristic of bee-pollinated taxa, as they are zygomorphic, creamy-green coloured with evident nectar guides. They also emit a weak but nice scent. However, they possess some characters attributed to bird-pollinated flowers such as a short, massive nectary spur and collenchymatous secretory tissue that closely resembles the one found in the nectaries of certain species that are thought to be bird-pollinated. This similarity in anatomical organization of the nectary, regardless of geographical distribution and phylogeny, strongly indicates convergence and appears to be related to pollinator-driven selection.

Key words: Dendrobium finisterrae, Orchidaceae, flower, nectary, micromorphology, spur anatomy, nectar, pollination

\section{INTRODUCTION}

Within the Orchidaceae family (the largest within angiosperms), the great diversity in the forms of flowers frequently reflects adaptation to pollination (Dressler, 1968; Johnson and Steiner,
2000; Fenster et al. 2004; Cozzolino and W i d m e r, 2005). The flower spur has a great adaptive significance, and it occurs in diverse taxonomic groups of orchids indicating multiple and independent evolution (Johns on and Ste in er, 1997, 2000). In orchids the origination of the spur can be diverse, and it can be formed by fusion of the proximal part of the labellum, as in Platanthera, Gymnadenia, or $\mathrm{Li}$ modorum (Figueiredo and Pais, 1992; S tpiczyńska, 1997; S tpiczyńska and Matusiew ic z, 2001). In Spirantheae, the spur is composed of the proximal parts of the lateral sepals, the lip and column (S in ger and S a z i ma, 1999), whereas in Hexisea imbricata, it is formed by fusion of the column and margins of the labellum (S t p i c z y ńs ka et al. 2005). Usually it is unilocular, but the spur divided into two locules occurs in Stereochilus dalatensis (S t piczyńska et al. 2011).

The spurs usually function as the place of nectar secretion and accumulation (S tpiczyńska, 2003 a,b; S t piczyńska et al. 2005; S tpiczyń$\mathrm{sk}$ a et al. 2011). However, in rewardless orchids the presence of a spur can be sufficient to attract pollinators (B e 11 et al. 2009).

The relationships between the shape and longevity of the nectary spur in orchids and the longevity of the mouth parts of pollinators have been studied intensively by many researchers, and particular attention has been devoted to Angraecum, the genus native to Madagascar and East Africa, with an enormous length of the spur (D a rw in, 1862; G a r a y, 1973; Nils son et al. 1987; W a s serthal, 1997). The structure of the spur and nectar secretion as an adaptation to pollination by Sphingidae were also investigated in Platanthera by S mith and S now (1976), 
Nils s on (1998), R oberts on and W at t (1990), Johs on (1997), Johns on and Steiner (1997), M a d (2000), M a d and Nils s on (2004), Little et al. (2005). The evolutionary trends in spur length in Aeridinae were studied by Topik et al. 2005 and Kocyan et al. 2008. According to Topik et al. 2005, a short spur represents the apomorphic state, and both loss and elongation of the nectary spur are considered to have occurred several times in the evolution of this group of orchids.

Dendrobium is a very large genus that comprises about 1200 species whose representatives noticeably differ in the forms of their spurs. However, in the literature there are no specific data on the structure of the spur in Dendrobium. The aim of the present paper was to investigate the morphological and anatomical organization of the spur nectary in Dendrobium finisterrae Schltr (syn.: Dendrobium melanolasium Gilli 1980, Sayeria finisterrae (Schltr.) R a u s ch e r t 1983) and to compare this structure to the spurs of other nectarsecreting orchids.

\section{MATERIAL AND METHODS}

Dendrobium finisterrae Schltr. is native to $\mathrm{Pa}-$ pua and New Guinea. This is a large sized epiphyte growing at high elevations (of 1300 to 2100 meters) and tolerant to relatively low temperatures. The plants bloom in the winter and the inflorescence is composed of several slightly fragrant flowers.

The investigated plant of Dendrobium finisterrae Schltr. 1912 was grown in the greenhouses of the Botanic Garden of University of Warsaw. The spurs were collected on the day of flower opening, and the nectaries were examined using light microscopy (LM), scanning electron microscopy (SEM), and transmission electron microscopy (TEM).

Small pieces of nectary tissue were fixed in $2.5 \%$ glutaraldehyde / $4 \%$ formaldehyde in phosphate buffer $(\mathrm{pH} 7.4 ; 0.1 \mathrm{M})$ for $2 \mathrm{~h}$ at ambient temperature, and afterwards they were carefully washed three times in phosphate buffer, and then post-fixed in $1.5 \%$ osmium tetroxide for $1.5 \mathrm{~h}$ and washed in distilled water two times for $5 \mathrm{~min}$. The fixed material was then dehydrated in graded ethanol series and finally, it was infiltrated and embedded in LR White resin. Afterwards, the material was cut at $60 \mathrm{~nm}$ for (TEM) with a Reichert Ultracut-S ultramicrotome and a glass knife, stained with uranyl acetate and lead citrate (Reynolds, 1963) and examined using a FEI Technai G2 Spirit Bio TWIN transmission electron microscope, at an accelerating voltage of $120 \mathrm{kV}$. Images were captured using a Megaview G2 Olympus Soft Imaging Solution camera.
Semi-thin sections $(0.9-1.0 \mu \mathrm{m}$ thick) were prepared for (LM) and stained with $1 \%(\mathrm{w} / \mathrm{v})$ aqueous methylene blue-Azur B solution. Hand-cut sections of fresh material were tested for the presence of starch and lipids with IKI solution and alcoholic Sudan III solution, respectively. The stained sections were viewed with a Nikon Eclipse E200 LM microscope. The presence of lipids in the nectary tissue was additionally tested with auramine $\mathrm{O}$, and the staining reaction was examined by means of a Nikon Eclipse 90i microscope equipped with a fluorescein isothiocyanate filter.

In order to examine the details of the nectary surface, the spurs were cut longitudinally and were subsequently dehydrated in acetone, subjected to critical-point drying using liquid $\mathrm{CO}_{2}$, sputter-coated with gold and examined by means of a TESCAN/VEGA LMU scanning electron microscope, at an accelerating voltage of $30 \mathrm{kV}$.

\section{RESULTS}

The flowers of Dendrobium finisterrae are yellow-green coloured, with purple and mahogany spots (Figs 1-2). The sepals and base of the flower are pale green and densely covered with stiff multicellular hairs. The lip is wavy with bright mahogany stripes that function probably as the nectar guides. The lateral petals are slightly twisted and bright-yellow coloured.

The spur is saccate, on average $10 \mathrm{~mm}$ in length, while the average diameter of the lumen at the proximal part is $4 \mathrm{~mm}$. The surface of the inner wall of the spur is wavy or covered with elongated grooves, and dark-red marks are also present inside (Fig. 3). The longitudinal section of the spur indicates the presence of the secretory area (nectary) exclusively at the distal part of the spur, and at that place the epidermal and subepidermal cells are distinguished by an intense green colour, whereas the non-secretory areas located above are pale green to creamy-coloured (Fig. 3). Just above the nectary, the lumen of the spur is laterally compressed forming a kind of nectary chamber at the bottom (Fig. 3).

The size of epidermis cells visible in SEM in the secretory area is $41.0 \mu \mathrm{m} \times 13.9 \mu \mathrm{m}$, on average. The surface of the epidermis is glabrous and covered with a slightly wrinkled cuticle (Fig.4). In the cuticle, pores or cracks are not visible. On the surface of the epidermis, nectar residues are present (Fig 4). They are absent in the proximal part of the spur.

On the transverse section, the wall of the spur in the nectary area has a thickness of $1 \mathrm{~mm}$, on average. It is composed of a single layer of secretory epidermis and several layers of small and compactly arranged 
subepidermal secretory cells and underlying ground parenchyma (Figs 5, 6, 7). Several vascular bundles run in ground parenchyma close to the nectary tissue and they are surrounded by strands of sclerenchymatous fibers (Fig. 5).

The secretory cells contain a large nucleus, dense parietal cytoplasm, and usually one large and centrally positioned vacuole. In the vacuoles, both in the secretory and parenchymatous cells, phenolic content is present (Figs 5, 6). Additionally, druses or regular crystals of calcium oxalate are found in the vacuoles of the secretory cells (Fig. 8), but in the ground parenchyma cells raphides are present. The
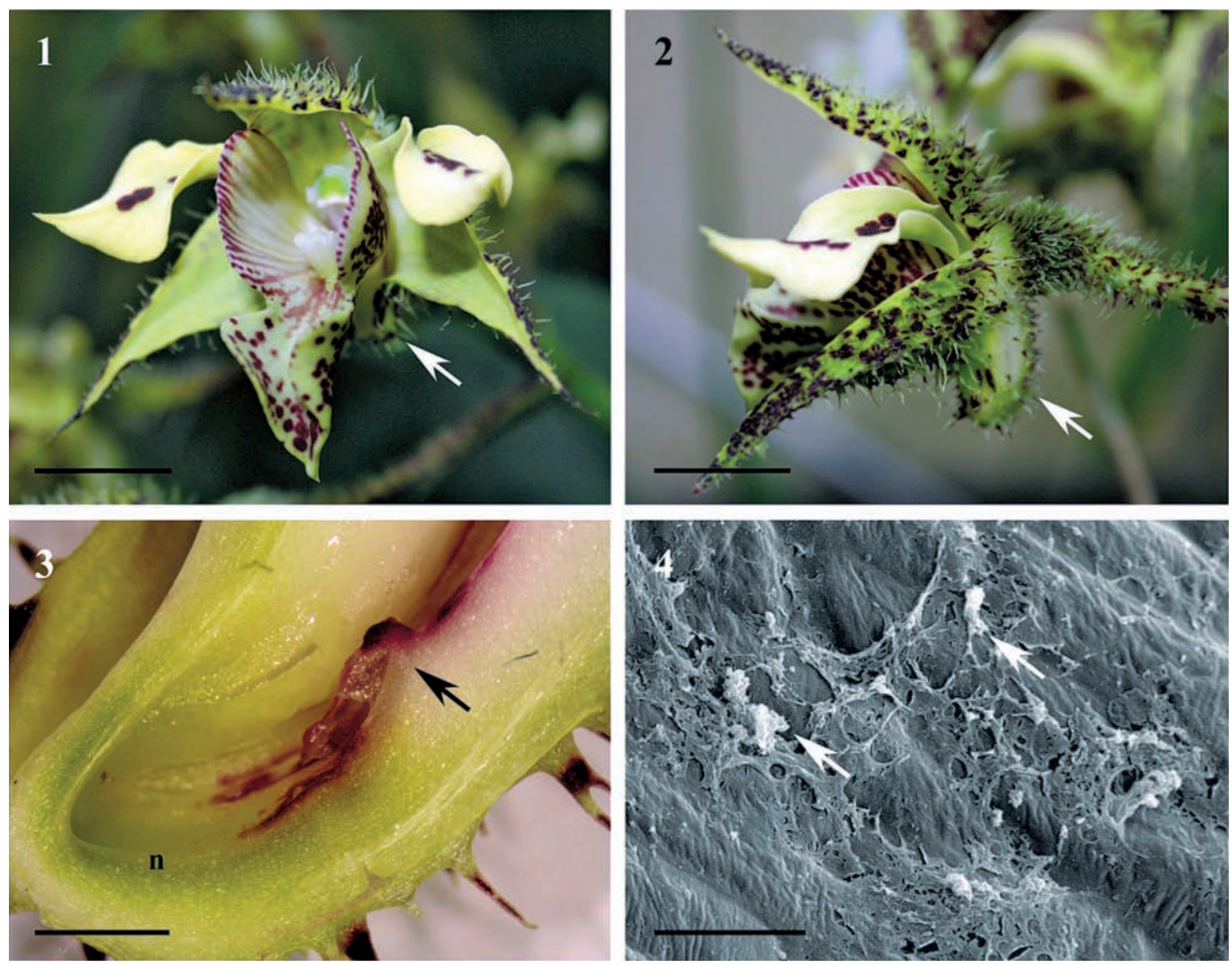

Fig. 1. Habit of the flower of D. finisterrae with dark-coloured marks on the labellum, the spur indicated by arrow. Scale bar $=10 \mathrm{~mm}$.

Fig. 2. The saccate spur (arrow) and the adaxial surface of the sepals covered with stiff hairs. Scale bar=10mm.

Fig. 3. Secretory area at the bottom of the spur, compression above (arrow) enclosing the nectary chamber. Scale bar=2mm.

Fig.4. Glabrous nectary epidermis cells covered with remnants of secretion (arrows). Scale bar=20 $\mu$ m 

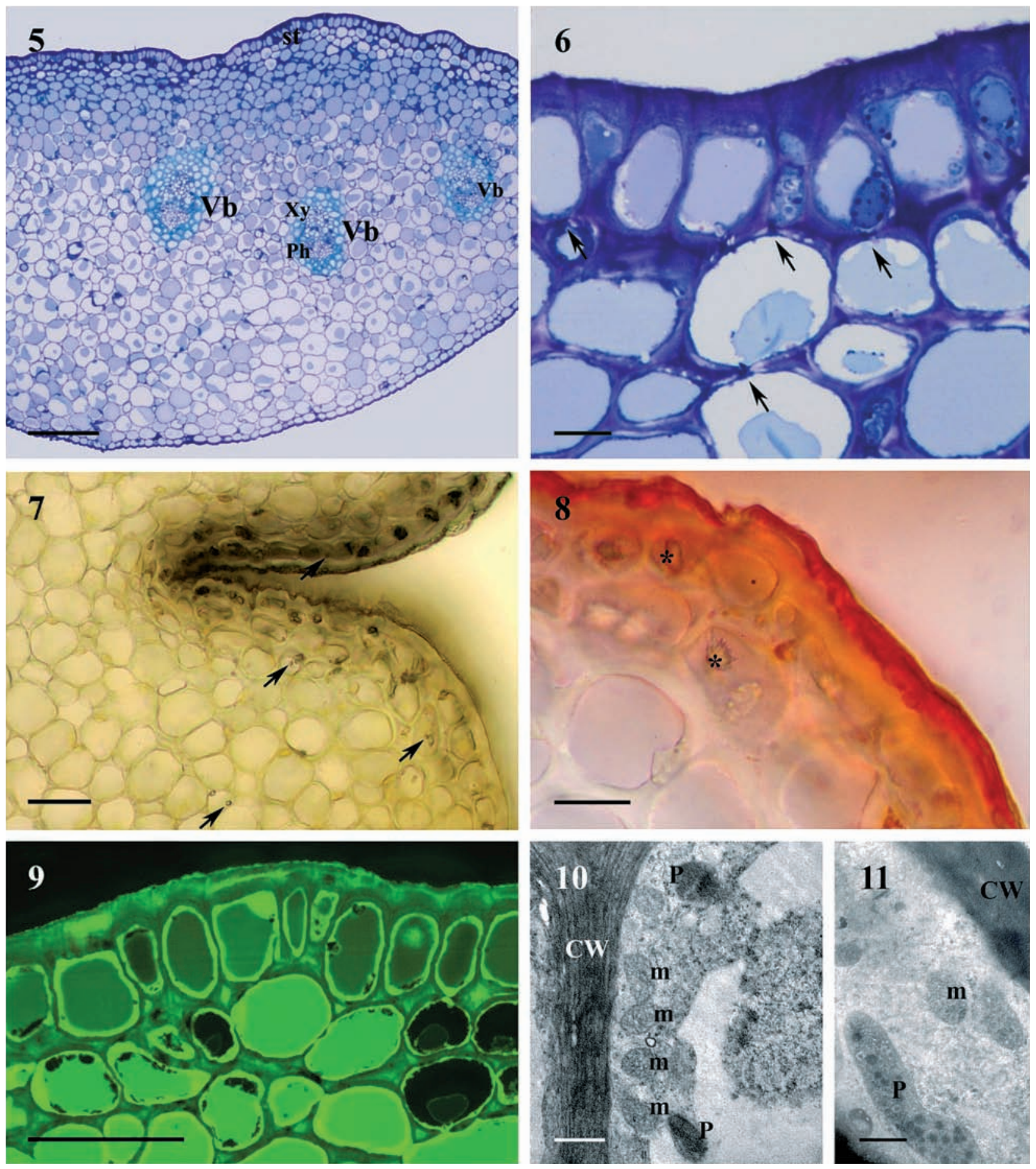

Fig. 5. Transverse section of the bottom part of the spur with the secretory tissue and vascular bundles that run in ground parenchyma. Scale bar $=200 \mu \mathrm{m}$.

Fig. 6. Details of secretory tissue. Nectary cells with parietal cytoplasm, large vacuole and thick cell walls. Primary pits indicated by arrows. Scale bar=20 $\mu \mathrm{m}$.

Fig. 7. Starch grains (arrows) stained with IKI in epidermal and parenchyma cells. Scale bar=100 $\mu \mathrm{m}$.

Fig. 8. Cuticle on the surface of the secretory epidermis stained in red with Sudan III. In the vacuoles small druses (asterisks) are present. Scale bar $=20 \mu \mathrm{m}$.

Fig. 9. Secretory epidermis with the cuticle only weakly stained with auramine O. Thick cell walls of secretory cells have no barriers for appoplastic nectar transport. Scale bar $=50 \mu \mathrm{m}$.

Fig. 10. Numerous mitochondria in the parietal cytoplasm of the subepidermal secretory cell. Scale bar=1nm.

Fig. 11. Irregular plastid with numerous plastoglobules in the secretory cell. Scale bar $=1 \mathrm{~nm}$ 


\section{DISCUSSION}

D. finisterrae possess zygomorphic, yellowgreen flowers with evident honey guides in the form of dark-purple spots and stripes. Additionally, the flowers are weakly fragrant. These features are characteristic of species pollinated by hymenoptera and thus, in terms of floral morphology and colour combinations, the investigated species resembles bee-pollinated species (van der Pijl and Dodson, 1969; Proctor and Yeo, 1973; Proctor, Yeo and Lack, 1996; v an d e r C in ge 1, 2001). However, the whole flower of $D$. finisterrae is extraordinary rigid. Also, the nectary is composed of thick-walled epidermis and collenchymatous subepidermal secretory tissue similar to that found in presumed ornithophilous species such as Maxillaria, Hexisea, and Ascocentrum (S t p i czyńska and Davies, 2006; Stpiczyńska et al. 2004, 2005, 2009, 2011). The spur in D. finisterrae is relatively short and saccate, and morphologically similar to that of some Aeridinae species, such as Ascocentrum curvifolium, A.garayi, A.ampullaceum, or Schoenorchis gemmata (Stpiczyńska et al. 2011). Therefore, the flowers of Dendrobium finisterrae share both the characteristic features of bee- and bird-pollinated flowers. Unfortunately, up to now there are no convincing reports on pollinators of this Dendrobium species. According to To pi k et al. (2005) short-spurred species of Aeridinae are mainly pollinated by bees and beetles, whereas the species having long spurs are generally pollinated by moths.

In $D$. finisterrae, lateral compression of the spur formed a kind of nectary chamber at the bottom. A similar structure in the spur was also noted in certain Aeridinae species, including both ornithophilous (e.g. Ascocentrum garayi) and entomophilous (e.g. Schoenorchis gemmata and Stereochilus dalatensis) taxa. Such structures, acting as nectar covers, can be interpreted as protection against nectar thieves or evaporation, or protection against raindrops.

The spur of D. finisterrae has a glabrous inner epidermis, and similar morphology of secretory epidermis has also been recorded for bee-pollinated species, such as Aerides crassifolia C.S.P. Parish ex Burb. (Ko c y a n et al. 2008), and in other putatively bee-pollinated species, such as Sedirea japonica or Schoenorchis gemmata (S t p i c z y ń s k a et al. 2011). By contrast, the internal surface of the nectary spur of Platanthera bifolia, P. chlorantha, Gymnadenia conopsea, several Ascocentrum spp., and Papilionanthe vandarum, is pubescent to hirsute and it has been noted in bird-pollinated and moth pollinated species. These hairs are thought to increase the total surface area for very intense nectar secretion (Davies and $\mathrm{Stpi-}$ c z y ń s k a , 2008 and references therein).
The nectary tissue in Dendrobium was supplied by several vascular bundles attached by sccerenchymatous fibres. Vascular strands were also abundant in the spurs of other investigated species, with usually two large and several smaller vascular bundles (S t p i c z y ńska et al. 2011). Generally, nectar sugars are transported to the secretory tissue by the phloem and from here, they pass to the secretory cells, via either the symplast or apoplast pathway. In D. finisterrae both forms of transport can co-exist, since in the thick cellulosic cell walls numerous pit fields are present, and no barriers to apoplastic transport are present in the cell walls. A similar mode of sugar transport within the nectary tissue has been recorded for a number of other taxa (Fahn, 2000; S tpiczyńska et al. 2004; N e p i, 2007).

Anatomically, the nectary spurs of D. finisterrae closely resemble the nectaries in bird pollinated taxa, such as those of Asiatic Aerides spp. or Neotropical species of Maxillariinae Benth. (Ornithidium coccineum, O. sophronitis), Laeliinae Benth. (Hexisea imbricata), and Oncidiinae Benth. (Symphyglossum sanguineum (Rchb.f.) Schltr.), especially in their possession of the collenchyma ( $\mathrm{Stpiczynska}$ et al. 2011; S tpiczyńska et al. 2004, 2005, 2009; S tpiczyńska and Davies, 2006). This massive tissue may protect the nectary during the visits of relatively large pollinators and, additionally, it can provide an apoplastic route for nectar movement at the level of the nectary tissue.

Amyloplasts were not a dominant form of plastids in the nectary cells of $D$. finisterrae, but few starch grains were accumulated both in the secretory cells and ground parenchyma. In many investigated taxa, starch grains are abundant in amyloplasts at the presecretory stage, but as the secretory activity of the nectary progresses, they disappear and plastids develop irregular profiles ( $\mathrm{N} \mathrm{e} \mathrm{p} \mathrm{i,} \mathrm{2007).} \mathrm{Starchless} \mathrm{pla-}$ stids in the nectary cells have also been observed in Gymnadenia conopsea (L.) R. Br. (S t p i c z y ń s ka and Matusiewicz, 2001), O. coccineum, and O. sophronitis (Stpiczyńska et al. 2004, 2009), and here sugars present in the nectar are probably delivered in the phloem. The plastids within the secretory cells of $D$. finisterrae frequently contained numerous osmoglobules. This character of plastids is frequently noted in nectary cells, and osmophilic material in the plastids was particularly evident in $P$. vandarum, where such plastids might be involved in the synthesis of secondary metabolites (S t p i c z y ń s k a et al. 2011).

In $D$. finisterrae, the cuticle overlying the secretory epidermis lacks pores and cracks, and the nectar probably passes through a relatively thick cuticle that intensely stained with Sudan III indicating the presence of lipids. However, staining with auramine $\mathrm{O}$ was 
not so evident. A similar result of staining with auramine O was noted in S. gemmata and S. dalatensis, $S$. japonica (S t p ic z y ńs ka et al. 2011) and non-orchid species Fritillaria meleagris (unpublished data), and this can indicate that a thick layer of cuticle is not a barrier for secreted and resorbed nectar, as recorded for Platanthera bifolia (L.) Rich. and P. chlorantha Custer ex Rchb. (S t p i c z y ń s k a, 1997, 2003b, c).

Despite the fact only one species was investigated in the present study, a comparison to other species with the nectary spur can indicate that the occurrence of similar morphological and anatomical organization in orchid taxa with various distribution throughout the world and assigned to other sub-tribes is strongly indicative of convergence and thus appears to be related more to pollinator-driven selection. Given the enormity of Dendrobiinae and the general lack of information on the structure of the nectaries in this subtribe, comparative studies on the structure of the spur in the genus Dendrobium will be continued to improve our current knowledge and understanding of floral diversity in this sub-tribe.

\section{REFERENCES}

Bell A.K., Roberts D.L., Hawkins J.A., Rudall P.J., Box M.S., Bateman R., 2009. Comparative micromorphology of nectariferous and nectarless labellar spurs in selected clades of subtribe Orchidinae (Orchidaceae). Bot. J. Lin. Soc. 160: 369-387.

Cozzolino S., Widmer A., 2005. Orchid diversity: an evolutionary consequence of deception? Trends Ecol. Evol. 20: 487-494.

Darwin C., 1862. On the various contrivances by which British and foreign orchids are fertilized by insects and on the good effects of intercrossing. John Murray. London.

Davis K.L., Stpiczyńska M., 2008. The anatomical basis of floral, food-reward production in Orchidaceae. In: Texeira da Silva JA (Ed.) Floriculture, Ornamental and Plant Biotechnology V: 392-407. Global Science Books, UK.

Dress le r R.L., 1968. Pollination by Euglossine bees. Evolution, 22: 202-210.

Fahn A., 2000. Structure and function of secretory cells. Adv. Bot. Res. 31: 37-75.

Fenster C.B., Armbruster W.S., Wilson P., Dudash M.R., Thomson J.T., 2004. Pollination syndromes and floral specialization. Annu. Rev. Ecol. Evol. S. 35: 375-403.

Figueiredo A.C.S., Pais M.S., 1992. Ultrastructural aspects of the nectary spur of Limodorum abortivum (L) Sw. (Orchidaceae). Ann. Bot. 70: 325-331.

Garay L.A., 1973. Systematics of the genus Angraceum (Orchidaceae). Kew Bulletin, 28: 495-516.
J ohn s on S.D., 1997. Pollination ecotypes of Satyrium hallackii (Orchidaceae) in South Africa. Bot. J. Linn. Soc. 123: 225-235.

Johns on S.D., Steiner K.E., 1997. Long-tongues fly pollination and evolution of floral spur length in the Disa draconis complex (Orchidaceae). Evolution, 51: 45-53.

Johns on S.D., Steiner K. E., 2000. Generalization versus specialization in plant pollination systems. Trends Ecol. Evol. 15(4):140-143.

Kocyan A., de Vogel E.F., Conti E., Gravendeel B., 2008. Molecular phylogeny of Aerides (Orchidaceae) based on one nuclear and two plastid markers: a step forward in understanding the evolution of the Aeridinae. Mol. Phylogenet. Evol. 48: 422-443.

Little K.J., Dieringer G., Romano N., 2005. Pollination ecology, genetic diversity and selection on nectar spur length in Platanthera lacera (Orchidaceae). Plant. Spec. Biol. 20: 183:190.

Ma ad J., 2000. Phenotypic selection in hawkmoth-pollinated Platanthera Bifolia: Targets and fitness surfaces. Evolution, 54(1): 112-123.

Maad J., Nilss on A., 2004. On the mechanism of floral shifts in speciation: gained pollination efficiency from tongue - to eye - attachment of pollinia in Platanthera (Orchidaceae). Biol. J. Linn. Soc. 83: 481-495.

Nepi M., 2007. Nectary structure and ultrastructure. [In:] S. W. Nicolson, M. Nepi, E. Pacini (eds), Nectaries and nectar. Springer, Dordrecht.

Nils s o n L.A., 1998. Deep flowers for long tongues. Trends Ecol. Evol. 13: 259-260.

Nilsson L.A., Jonsson L., Ralison L., Randrianjohany E., 1987. Anagraecoid orchid and hawkmoths in central Madagascar: specialized pollination systems and generalist foragers. Biotropica, 19: 310-318.

Proctor M., Yeo P., 1973. The pollination of flowers. Colins, London, UK.

Proctor M., Yeo P., Lack A., 1996. The natural history of pollination. London: Harper Collins.

Reynolds E.S., 1963. The use of lead citrate at high $\mathrm{pH}$ as an electron-opaque stain in electron microscopy. J. Cell Biol. 17: 208-213.

Robertson J.L., Wyatt R., 1990. Reproductive biology of the yellow-fringed orchid, Platanthera ciliaris. Am. J. Bot. 77: 388-398.

Singer R.B., Sazi m a M., 1999. The pollination mechanism in the 'Pelexia alliance' (Orchidaceae: Spiranthinae). Bot. J. Linn. Soc. 131: 249-262.

Smith G.R., Snow G.E., 1976. Pollination ecology of Platanthera (Habenaria) ciliaris and P. blephariglottis (Orchidaceae). Bot. Gaz. 137(2): 133-140.

Stpiczyńska M., 1997. The structure of nectary of Platanthera biforia L. (Orchidaceae). Acta Soc. Bot. Pol. 66: 5-11.

S t pi c z y ń s k a M ., 2003a. Floral longevity and nectar secretion in Platanthera chlorantha (Custer) Rchb. Ann. Bot. 92: 191-198. 
Stpiczyńska M., 2003b. Nectar resorption in the spur of Platanthera chlorantha (Custer) Rchb. - structural and microautoradiographical studies. Plant Syst. Evol. 238: 119-126.

St piczyńska M., 2003c. Incorporation of 3H-sucrose after the resorption of nectar from the spur of Platanthera chlorantha (Custer) Rchb. Can. J. Bot. 81: 927-932.

Stpiczyńska M., Davies K.L., 2006. Nektary structure in Symphyglossum sanguineum (Rchb.f.) Schltr. (Orchidaceae). Acta Agrobot. 59: 7-16.

Stpiczyńska M., Matusiewicz J., 2001. Anatomy and ultrastructure of the spur nectary of Gymnadenia conopsea L. (Orchidaceae). Acta Soc. Bot. Pol. 70: 267-272.

Stpiczyńska M., Davies K.L., Gregg A., 2004. Nectary structure and nectar secretion in Maxillaria coccinea (Jacq.) L.O. Williams ex Hodge (Orchidaceae). Ann. Bot. 93: 87-95.

Stpiczyńska M., Davies K.L., Gregg A., 2005. Comparative account of nectary structure in Hexisea imbricata (Lindl.) Rchb. f. (Orchidaceae). Ann. Bot. 95: 749-56.

Stpiczyńska M., Davis K.L. Gregg A., 2009. Nectary structure of Ornithidium sophronitis Rchb.f. (Orchidaceae: Maxillariinae). Acta Agrobot. 62(2): 3-12.

Stpiczyńska M., Davies K.L., Kamińska M., 2011. Comparative anatomy of the nectary spur in selected species of Aeridinae (Orchidaceae). Ann. Bot. 107: 327-345

Topik H., Yukawa T., Ito M., 2005. Molecular phylogenetics of subtribe Aeridinae (Orchidaceae): insights from plastid matK and nuclear ribosomal ITS sequences. J. Plant Res. 118: 271-284.

van der Cingel N.A., 2001. An atlas of orchid pollination - America, Africa, Asia and Australia. A.A. Balkema, Rotterdam, Netherlands.

van der Pij1 L., Dods on C.H., 1969. Orchid flowers: their pollination and evolution. Coral Gables, Florida: University of Miami Prees.

Wasserthal L.T., 1997. The pollinators of the malagasy star orchids Angraceum sesquipedale, A. sororium and A. compactum and the evolution of extremely long spurs by pollinator shift. Bot. Acta, 110: 343 .

\section{Budowa nektarnika ostrogowego u Dendrobium finisterrae Schltr. (Dendrobiinae, Orchidaceae)}

\section{Streszczenie}

W niniejszej pracy po raz pierwszy opisano budowę anatomiczną i ultrastrukturę ostrogowego nektarnika u Dendrobium finisterrae Schltr. i porównano jego strukturę z nektarnikami innych taksonów. Badania prowadzono przy użyciu mikroskopu świetlnego (LM), skaningowego elektronowego (SEM) $i$ transmisyjnego elektronowego (TEM). Nektarnik jest zbudowany z jednowarstwowej epidermy oraz kilku warstw subepidermalnie położonych drobnych, ściśle do siebie przylegających komórek wydzielniczych. Komórki wydzielnicze mają grube, celulozowe ściany $\mathrm{z}$ jamkami prostymi. Tkanka wydzielnicza jest zaopatrywana przez wiązki przewodzące, które znajdują się w usytuowanym poniżej miękiszu zasadniczym. Wiązki otoczone są pochwami sklerenchymatycznymi. Stwierdzono, że kwiaty badanego gatunku wykazują szereg cech charakterystycznych dla taksonów zapylanych przez owady błonkoskrzydłe, ponieważ są zygomorficzne i mają barwę kremowo-zieloną z wyraźnie widocznymi wskaźnikami. Kwiaty te emitują również słaby, przyjemny zapach. U Dendrobium finisterrae zaobserwowano także niektóre cechy związane z ornitofilią, takie jak krótkie, masywne ostrogi oraz kolenchymatyczne komórki sekrecyjne, co upodabnia je do nektarników niektórych gatunków zapylanych przez ptaki. Podobieństwa w budowie anatomicznej nektarnika notowane u różnych taksonów niezależne od ich występowania i pokrewieństwa, mogą wskazywać na konwergencje związane z presją zapylaczy. 